\title{
First formulation of a botanical active substance extracted from neem cell culture for controlling the armyworm
}

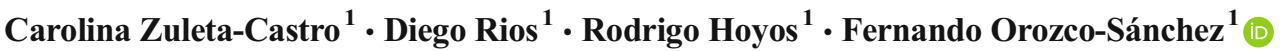

Accepted: 28 July 2017 / Published online: 29 August 2017

(C) INRA and Springer-Verlag France SAS 2017

\begin{abstract}
Neem (Azadirachta indica) produces several of compounds known as limonoids, which have an antifeedant effect on insects. These compounds are extremely sensitive to some environmental factors that cause their degradation. Despite this, they are widely used in many formulations of commercial bioinsecticides. We evaluated the photodegradation of the crude extract from A. indica cell culture and designed the formulation of a botanical active substance for controlling insects. The crude extract was subjected to $368 \mathrm{~nm}$ UV light for $24 \mathrm{~h}$, and its degradation was examined. Limonoids present in the crude extract were analyzed via high-performance liquid chromatography (HPLC). The composition of some compounds in the extract decreased by 55\% after $214 \mathrm{~min}$ and $83 \%$ after $1440 \mathrm{~min}$. For the insect bioassay, we prepared six formulations containing ethanolic extracts from $A$. indica cell culture as the active ingredient. The formulation also contained a photoprotector and two stabilizers, emulsified with water, castor oil, and Tween 80 . Formulations were subjected to stability tests, and the relative phase separation was assessed. To evaluate their biological activity, the antifeedant index and the affected leaf area on corn infested with Spodoptera frugiperda were determined using laboratory- and field-scale bioassays. Three formulations showed good stability, and two presented the highest antifeedant indices (98.5 and 99.7\%) in laboratory-scale bioassays. They provided the greatest field-level protection (leaf areas affected were 0.6 and $1.9 \%$, respectively). Therefore, the emulsion containing $0.76 \% p / p$ ethanolic extract, $0.72 \%$ 8-hydroxyquinoline, $1.00 \%$ anthraquinone and epichlorohydrin, $0.20 \%$ Tween 80 ,
\end{abstract}

Fernando Orozco-Sánchez

feorozco@unal.edu.co

1 Universidad Nacional de Colombia Sede Medellín, Medellín, CP 05001000, Colombia and 50/50 aqueous phase/oil phase was selected as the best formulation for the insect biocontroller. This thus addresses the problem of metabolite degradation in the field. To our knowledge, this is the first effective formulation of a botanical active substance for controlling insects using A. indica cell culture extract.

Keywords Neem · Plant cell culture $\cdot$ Limonoids · Photodegradation $\cdot$ Emulsion $\cdot$ Botanical active substance . Physical stability $\cdot$ Affected leaf area $\cdot$ Armyworm

\section{Introduction}

Neem (Azadirachta indica A. Juss.) is a tree found in India and Burma, which exhibits a variety of medicinal properties. It has been studied worldwide because of its ability to produce secondary metabolites that have antifeedant effects on some insects. One of the most important species of insects studied is Spodoptera frugiperda, a tropical endemic insect from the Western Hemisphere, where its populations extend from Argentina to North America (López et al. 1999; Martinelli et al. 2007). This insect is well known in the agricultural field because of its aggressive attack on several crops of economic importance such as corn (Zea mays), cotton (Gossypium spp.), and rice (Oryza sativa). On the other hand, secondary metabolites of neem have complex structures, which makes their chemical production difficult. Accordingly, much research has been carried out on the in vitro production of these substances. At the Universidad Nacional de Colombia Sede Medellín, A. indica cell culture has been established, and investigations to determine the bioactivity of extracts from these cultures are underway. The median lethal dose $\left(\mathrm{LD}_{50}\right)$ of extracts 
from $A$. indica cell cultures in S. frugiperda was determined, as well as their antifungal activity in dermatophyte fungi (Trujillo et al. 2008; Ospina 2012). In addition, we evaluated the use of abiotic elicitors for neem metabolite production (Capataz 2005; Capataz et al. 2007). The secondary metabolites produced in vitro are sensitive to factors such as ultraviolet light, $\mathrm{pH}$, and temperature (similar to metabolites produced in vivo, Srivastava and Srivastava 2011). These factors favor the breakdown of secondary metabolites to other substances possessing no biological activity (Barrek et al. 2004). Limonoids may also be prone to degradation when exposed to these factors. Previous investigations by our research group proved the effectiveness of crude extracts from neem cell culture, and we determined that these were degraded by contact with light and heat. This is the principal disadvantage of using extracts from $A$. indica cell culture as plague controller agents. Considering this, a series of experiments was conducted to evaluate the photodegradation of this extract and to improve its effectiveness in agricultural applications by using different additives. The formulation for a botanical active substance based on neem cellular suspension extracts was then designed. This formulation contained a photoprotector (8-hydroxiquinoline), two stabilizers (anthraquinone and epichlorohydrin), a surfactant (Tween 80), water, and castor oil. The effectiveness of the formulation was tested in S. frugiperda in the laboratory and the field (Fig. 1).

\section{Materials and methods}

\subsection{Plant material}

The biomass used for extractions was obtained from $A$. indica cell cultures. These cultures were grown from friable calluses established from seeds (Capataz et al. 2007), and cell suspensions were cultivated in 500-mL shake flasks with the same culture medium used for calluses, and without a gelling agent (Capataz et al. 2007). Cultures were incubated in the dark at $25 \pm 1{ }^{\circ} \mathrm{C}$ and shaken at $120 \mathrm{rpm}$. Subcultures were prepared every 10 days.

\subsection{Limonoid degradation experiments}

Lyophilized biomass from cell cultures was subjected to percolation using methanol as a solvent. The obtained solution was completely evaporated to remove the methanol. The limonoids in this extract were separated using dichloromethane (Capataz et al. 2007). Photodegradation experiments were carried out using a photoreactor (Centricol Ltda.) to evaluate possible metabolite degradation, with the light source placed $10 \mathrm{~cm}$ away from the extracts. The wavelength required for maximum absorption in the extract was previously determined (368 nm), and two main signals were identified. A 368-nm Sylvania ${ }^{\circledR}$ ultraviolet lamp was therefore used in the experiments. The temperature was maintained at $35 \pm 1{ }^{\circ} \mathrm{C}$. A methanolic solution of extract $(1.500 \pm 0.001 \mathrm{~mL})$ at $8163.629 \pm 0.005$ ppm was deposited in Petri dishes. Different samples were analyzed at two exposure times (214 and $1440 \mathrm{~min}$ ).

All samples were diluted with high-performance liquid chromatography (HPLC)-grade methanol, and the limonoids were analyzed using HPLC (HP1100; Agilent Technologies, USA). A LichroCART 125-4 LiChrospher 100 RP-18 column $(125 \times 4.6 \mathrm{~mm}$ I.D, pore diameter, $5 \mu \mathrm{m}$, Merck®, Germany) was used as the stationary phase. The mobile phase flow rate was $1 \mathrm{~mL} / \mathrm{min}$, and the composition was controlled via a linear gradient of acetonitrile/water starting at 70:30 and finishing at 10:90 after $30 \mathrm{~min}$. Injection volume was $50 \mu \mathrm{L}$, and the absorbance of limonoids was measured at $214 \mathrm{~nm}$ by means of a diode array detector. Limonoid peaks in the samples were compared to azadirachtin as the standard (Sigma, USA; catalog no. A-7430, Giraldo et al. 2002).

\subsection{Ethanolic extractions for botanical active substance formulation}

Ethanol was used as the extraction solvent for botanical active substance formulation, because of its low toxicity and food industry approval. The biomass was freeze-dried and macerated in a mortar, before weighing and mixing with $96 \%$ ethanol in a $1-\mathrm{L}$ flask (1-g dry biomass $/ 20 \mathrm{~mL}$ ethanol). This mixture was kept in the dark at $25 \pm 1{ }^{\circ} \mathrm{C}$ and shaken at $120 \mathrm{rpm}$ for $24 \mathrm{~h}$. The mixture was then filtered to separate the ethanolic extract and recover the biomass. The extraction process was carried out three times. Finally, extracts were mixed and concentrated in a rotatory evaporator until dry and kept in the dark until formulation.

\subsection{Formulation of the botanical active substance for controlling insects}

Initially, an emulsification process using water, castor oil, and Tween 80 was carried out. The water-in-oil (W/O) proportion was evaluated at 50/50 and $60 / 40 \% p / p$, and Tween 80 at $0.20,0.30$, and $0.40 \% p / p$. The most stable combination was selected as the basic emulsion. Emulsions were prepared following the phase inversion method (Adamson and Gast 1997). After a few hours, a reversible phase separation process occurred and generated two $\mathrm{O} / \mathrm{W}$ emulsions, one rich in oil and the other rich in water. Both phases could be homogenized again by manual shaking. Each phase height was measured and compared with the analogous one in a control mixture 
Fig. 1 Bioassays on

S. frugiperda. a Lab-scale

bioassay. b Field-scale bioassay

in the Cotové Agricultural Centre

(Universidad Nacional de

Colombia Sede Medellín)

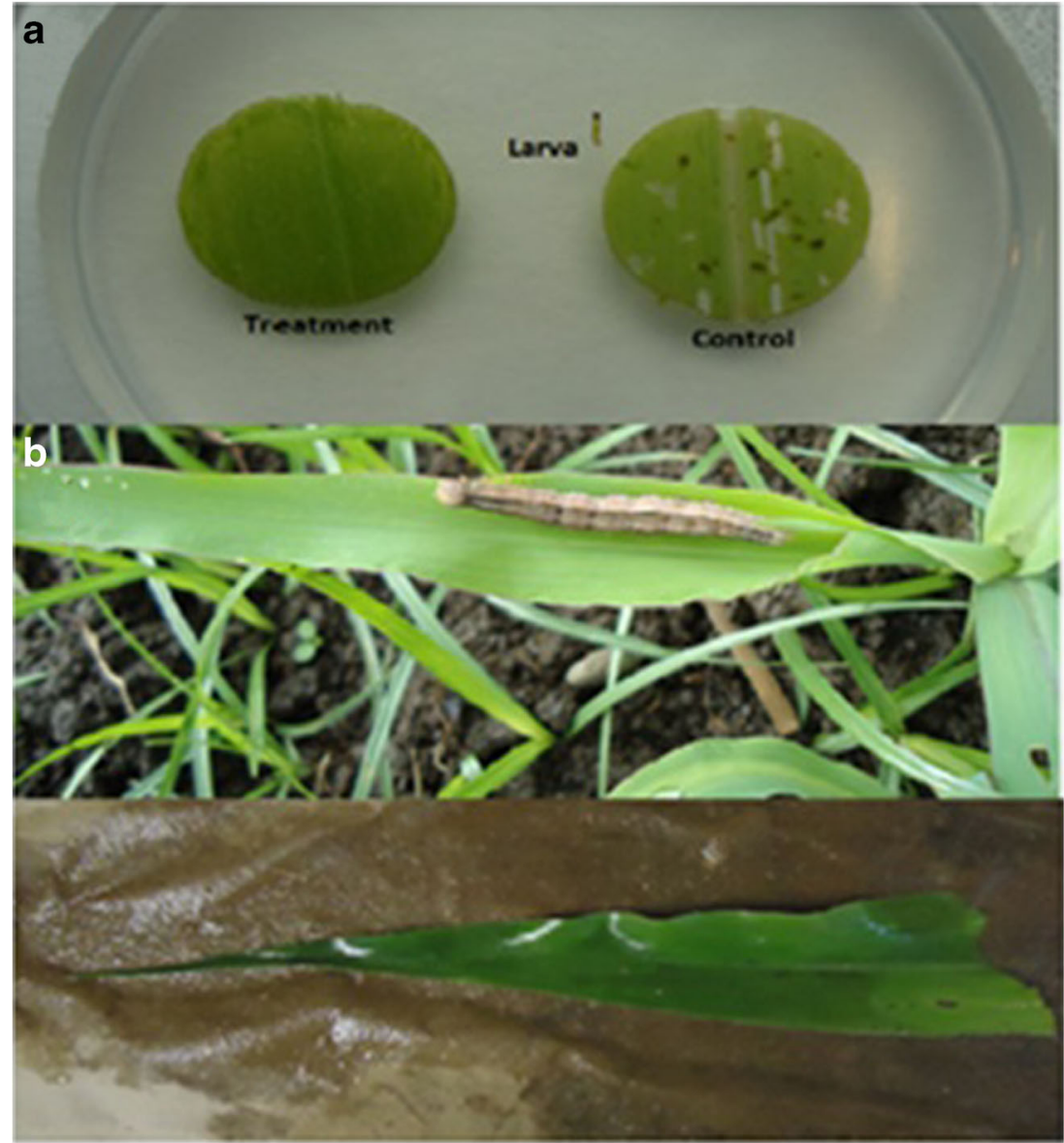

(water and castor oil without surfactant). These comparisons led to three relative indices of phase separation, as shown in the following equations.

Index $1=\frac{\text { Aqueous phase height }(\text { Treatment })}{\text { Water height }(\text { Control })}$
Index $2=\frac{\text { Visible oil height in oil phase }(\text { Treatment })}{\text { Oil height }(\text { Control })}$
Index $3=\frac{\text { Oil phase height }(\text { Treatment })}{\text { Oil height }(\text { Control })}$

Index 1 indicates the proportion and velocity with which the oil-rich phase separates from the emulsion. Index 3 describes the same behavior for the water-rich phase. The relative separation of the phase increases when these indices have a value close to 1 . On the other hand, when index 2 is greater than zero, it indicates that a fraction of the oil is irreversibly separated from the rest of the emulsion.

Once the base emulsion was established, other components were added to the formulation. 8-hydroxiquinoline was used as photoprotector at a ratio of $1: 1$ with the extract (Johnson et al. 2003). Anthraquinone and epichlorohydrin were used as stabilizers at 0.50 and $1.00 \% \mathrm{p} / \mathrm{p}$, respectively, in a formulation similar to that of Kumar and Parmar (1999). Furthermore, the extract was evaluated at three concentrations $(0.64,0.76$, and $0.89 \% \mathrm{p} / \mathrm{p})$. The formulations were diluted with the extract to be evaluated in lab-scale bioassays, following the method by Trujillo et al. (2008) and following the method by García and Carvajal (2010) for field-scale bioassays. Both bioassays were carried out using $S$. frugiperda. Emulsions containing the extract at $0.64 \% p / p$ were diluted to $0.25 \% \mathrm{p} / \mathrm{p}$. Similarly, the formulations at $0.76 \% p / p$ were diluted to $0.30 \% p / p$. Finally, formulations at $0.89 \%$ $p / p$ were diluted to $0.35 \% p / p$. The formulations were prepared using the phase inversion method.

\subsection{Lab-scale bioassays}

In this experiment, second instar larvae of $S$. frugiperda were used to evaluate the antifeedant effect of the designed formulations. An agar film was placed into Petri dishes, on which two discs of corn leaf were deposited. One of them was coated with the treatments and the other acted as a control. One of these treatments was ethanol $(96 \%)$ and was used to evaluate toxicity. A larva was then placed into the Petri dish (Fig. 1a). The antifeedant effect of the treatments was evaluated after 
$96 \mathrm{~h}$, and affected leaf area was measured in the corn leaf discs (Capataz et al. 2007). The antifeedant effect (A.F.E.) was calculated using the equation given by Kearney et al. (1994) and Blaney et al. (1990).

A.F.E $=\frac{\text { Affected disc area }(\text { Control })-\text { Affected disc area }(\text { Treatment })}{\text { Affected disc area }(\text { Control })+\text { Affected disc area }(\text { Treatment })} \times 100$

\subsection{Field-scale bioassays}

Experiments were carried out in the Cotové Agricultural Center (Universidad Nacional de Colombia). An area of $180 \mathrm{~m}^{2}$ was sowed with corn seeds (variety ICA V 109). The field was divided into three blocks of $60 \mathrm{~m}^{2}$, and each block was divided into 15 spaces of $4 \mathrm{~m}^{2}$. The treatments were evaluated in these spaces. Once a week, $150 \mathrm{~mL}$ of each formulation was applied, mixed with INEX-A, a product that improves adhesion of the biocontroller to the leaves. The application process began 20 days after the plants emerged and ended 15 days later. The effectiveness of the treatments was evaluated after $96 \mathrm{~h}$ by assessing the affected leaf area (Fig. 1b).

\section{Results and discussion}

\subsection{Extract degradation}

The extracted limonoids were injected into the HPLC system. The signals in the resulting chromatograms are shown in Fig. 2a. The signals shown correspond to $0 \mathrm{~min}$ of exposure, and their magnitudes were considered to be $100 \%$ of the concentration. The intensity of the signals decreased as the exposure time increased (214 and $1440 \mathrm{~min}$ ). This confirms that the extract was degraded by UV light during exposure.

The variations in signal 1 (retention time $12.357 \mathrm{~min}$ ) and signal 2 (retention time $16.543 \mathrm{~min}$ ) when the extract is exposed to ultraviolet light are shown in Fig. 2b. In both signals, a considerable degradation was observed before the end of the first $2 \mathrm{~h}$. This decreases for the next $2 \mathrm{~h}$, at which point the slope begins to significantly decrease. At $214 \mathrm{~min}$, the percentage composition of both signals declined by $55 \%$. At the end (1440 min), signal 1 had declined by $72 \%$ and signal 2, by $83 \%$. The method used to determine the half-life was defined by Wilhelm Ostwald (1888). The percentage degradation of signals 1 and $2(\mathrm{C})$ was calculated with the following relationship: [(Absorbance in $t=0-$ Absorbance in $t=t) /$ Absorbance $_{\text {in }}$ $t=0] \times 100$. Using a mathematical model of $\mathrm{C}$ vs. time (t) for each signal, the equations shown in Table 1 were obtained. The half-life for the degradation was calculated as the time corresponding to $C=50 \%$ (Ostwald 1888; Skoog et al. 2005; Cruz et al. 2013). The half-life and the equations obtained for the variation of signals 1 and 2 in the $A$. indica cell culture extract when subjected to photodegradation $(368 \mathrm{~nm})$ are shown in Table 1 . The regression coefficients of the equations were 0.99 .

These results indicate that the compounds in the extract degrade after UV radiation. There are several scientific reports that quantify this degradation. For example, azadirachtin (the most abundant limonoid in neem seeds) has a half-life of $48 \mathrm{~min}$ when it is subjected to radiation at $254 \mathrm{~nm}$ (Johnson and Dureja 2002). Degradation analyses of signals 1 and 2 were carried out for azadirachtin, as reported by Dureja and Johnson, (2000). In literature, no information was found about photodegradation of other limonoids in A. indica and there are no references to this behavior in extracts of this plant or neem cell culture.

\subsection{Ethanolic extractions}

The extract obtained exhibited organoleptic features, such as a dark brown color, a strong garlic smell, and a viscous consistency. These features concurred with those described by Rajpal (2005) and Villamil et al. (2012) for ethanolic extracts that were obtained from neem seeds. The extracts were obtained at a ratio of $0.22 \mathrm{~g}$ extract per gram of dried cells. At present, there are no reports of bioinsecticides or biocontrollers using neem cell culture ethanolic extract as the active ingredient, as most neem bioinsecticides are made from neem seed oil.

\subsection{Formulation of a botanical active substance for controlling insects}

Relative phase separation is increased when index 1 and 3 have values close to 1 , and index 2 has a value greater than 0 . The relative phase separation for each designed formulation is shown in Fig. 3a. Accordingly, the formulation made using Tween 80 and water/castor oil at a 50/50 ratio was the most stable (data not shown). The hydrophilic-lipophilic balance (HLB) for surfactants is a measure of their hydrophilic character: the higher the HLB, the greater the water affinity (Griffin 1949). HLB values for Tween 80 and Tween 20 are 15 and 16.7, respectively. Thus, Tween 80 should generate 
Fig. 2 Degradation in A. indica cell culture extracts. a

Degradation chromatograms of extract at 214 and $1440 \mathrm{~min}$ of light exposure. b Degradation percentage of signal 1 and signal 2 a Absorbance (mAU)

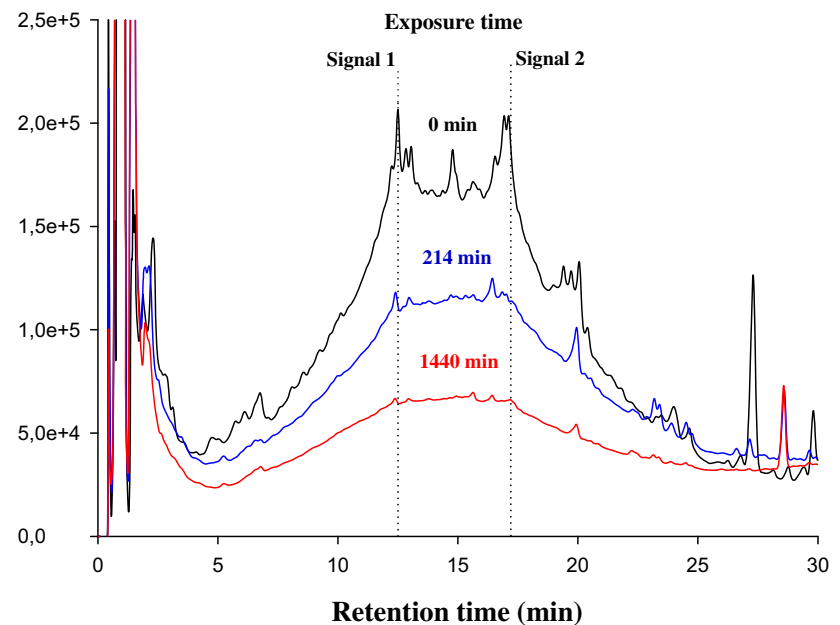

b Percentage composition (\%)

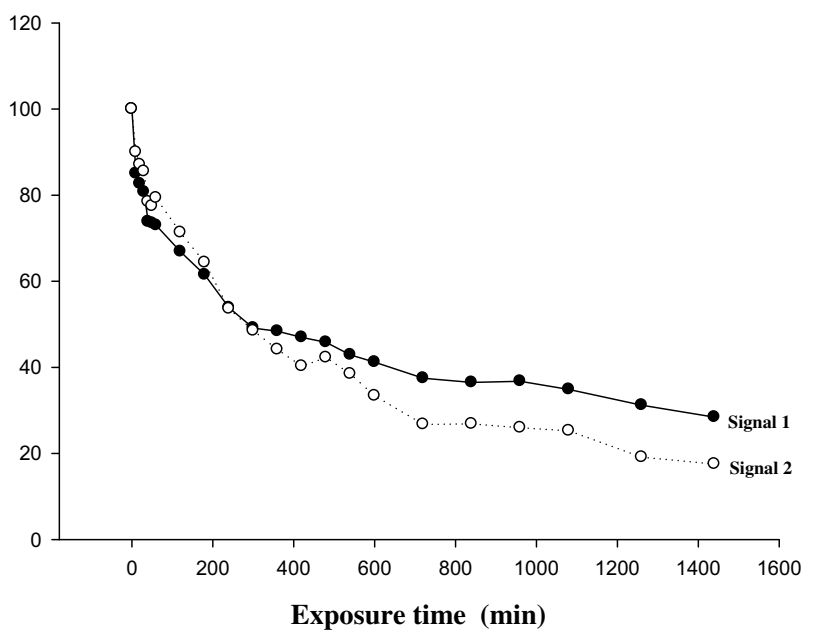

differences in the affected leaf area when treating with the formulations $F 1$ to F11 and the control (F13). This might be because larvae were kept in captivity, and these conditions may cause the insects to become selective about food. For example, during the investigation, larvae ate only fresh leaves and rarely ate mature or dehydrated leaves. This observation agrees with that by Ashley et al. (1985). In their experiments, the insects were shown to be selective with respect to the quality of the diet. It is therefore possible that any strange substance or agent in their diet was met with rejection. This behavior would explain why most formulations exhibit high antifeedant effects in the laboratory. In the case of treatment with the extract
Table 1 Half-life and resulting equations for photodegradation of signals 1 and 2 at $368 \mathrm{~nm}$. $t$ exposure time ( $\mathrm{min}), C$ composition $(\%)$

\begin{tabular}{clc}
\hline Retention time in min (compound) & Curve equation & Half-life (min) \\
\hline $12.357(1)$ & $\mathrm{C}=53.9086+38.2172 \times 10^{-0.0103 \times \mathrm{t}}-0.0185 \times \mathrm{t}$ & 302.7 \\
$16.543(2)$ & $\mathrm{C}=53.8696+38.6398 \times 10^{-0.0039 \times \mathrm{t}}-0.0175 \times \mathrm{t}$ & 516.1 \\
\hline
\end{tabular}

Affected leaf areas in the lab-scale bioassays are shown in Fig. $3 \mathrm{~b}$. According to these results, there was no large 
a Relative phase separation in formulations

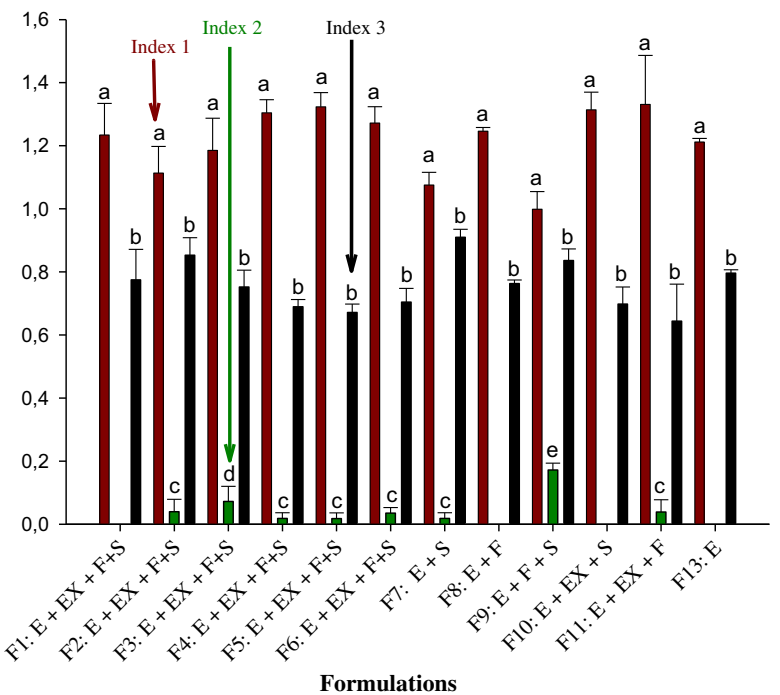

b Antifeedant effect of formulations in lab-scale bioassays (\%)

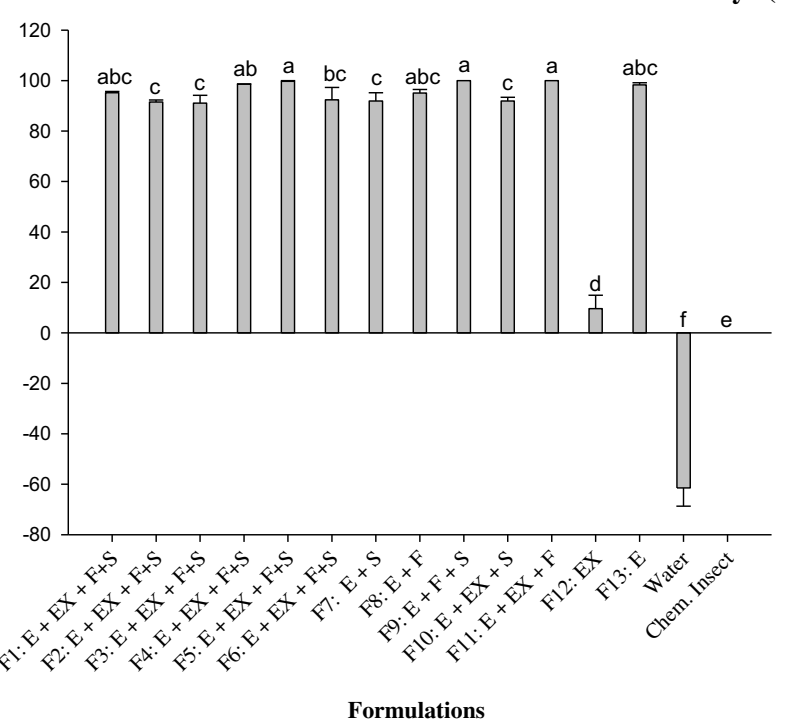

Fig. 3 Relative phase separation and activity in lab-scale bioassays. a Relative phase separation in formulations, $\mathbf{b}$ affected leaf area in lab-scale bioassays. Formulation composition: $E$ base emulsion, $E X$ extract, $P$ photoprotector, $S$ stabilizers, Chem Insect chemical insecticide (Ráfaga $\left.{ }^{\circledR}\right)$. Indices, antifeedant effects, and areas with the same letter do not exhibit significant differences, according to the Fisher LSD test $(p<0.05)$

(F12), the antifeedant effect was poor. This is possibly due to degradation of the extract compounds. For example, Johnson and Dureja (2002) reported that azadiracthin is degraded by light in $48 \mathrm{~min}$. In our experiment, the evaluation was carried out after $96 \mathrm{~h}$. Despite this, formulations 4 and 5 exhibited the greatest antifeedant effect and the lowest affected leaf area, because of the presence of the photoprotector and stabilizers, which improved the effectiveness of this extract.

\subsection{Field-scale bioassay}

The field bioassays were conducted on young corn plants (approximately 30 to $50-\mathrm{cm}$ tall), which are commonly devastated by the armyworm. The tests were carried out to compare formulation 4 (applied at $0.3 \%$ ) with the commercial products Ráfaga ${ }^{\circledR}$ insecticide (a chemical product applied at $0.5 \%$ ) and BioNeem ${ }^{\circledR}$ (applied at $0.6 \%$ ). Water was used as the control treatment. The data obtained in this phase of the investigation are shown in Fig. 4. Results under field conditions were different from those found in the laboratory-scale bioassays, perhaps because of behavioral differences between wild specimens and insects kept in captivity. It is probable that captive larvae became demanding and rejected food that did not satisfy their tastes, while wild insects can adapt easily to adverse conditions (Morales et al. 2011). We observed that formulations 4 and 5 provided the greatest protection to plants in the field, which agrees with the results of the laboratory-scale bioassays. Furthermore, these were the most stable formulations. In both cases, the antifeedant effect of the extracts was improved and the problems related to the loss of biological activity under UV light and metabolite degradation was solved. The difference between formulations 4 and 5 lies in the concentrations of the components. The first (4) has a lower quantity of extract and photoprotector, but has a higher stabilizer concentration. On the contrary, formulation 5 requires a lower quantity of stabilizer, but its extract and photoprotector concentrations are higher. Extract concentration is a decisive factor in formulation production. Therefore, formulation 4 was selected as the formulation for an insect biocontroller based on extracts from A. indica cell cultures.

The Ráfaga ${ }^{\circledR}$ insecticide is composed of chlorpyrifos, which are moderately toxic to humans but greatly so to amphibians, fish, and bees. BioNeem ${ }^{\circledR}$ contains neem seed ethanolic extract, and is manufactured in Colombia using seeds imported from India. Formulation 4 was very efficient and comparable to the commercial product BioNeem ${ }^{\circledR}$ and the chemical insecticide Ráfaga ${ }^{\circledR}$. Statistical tests showed no difference between the efficiency of these three products in the fight against the armyworm. NeemAzal ${ }^{\circledR}$ is an Indian product formulated from the vegetable extract of the neem tree. Avilés et al. (2001) reported that this product exhibited an effectiveness of $83 \%$ in controlling Thrips palmi in pepper fields, when it was applied at $0.05 \% \mathrm{v} / \mathrm{v}$. Susaimanickam et al. (2012) determined the effectiveness of a new formulation based on neem and pungam oils (PONNEEM), which controlled infestations such as Helicoverpa armigera and Spodoptera litura. This new product achieved a reduction of the oviposition process of $68.12 \%$ when applied at $20 \mu \mathrm{L} / \mathrm{L}$ in a labscale assay. Santos Pinto et al. (2013) reported that commercial product Neemseto $®$ controlled in $100 \%$ the cotton aphid (Aphis gossypii Glover). In another investigation, Ruiz et al. (2009) compared the effectiveness of azadirachtin (the most important neem tree metabolite) with two other chemical products (imidacloprid and oxamyl) in controlling the insect 
Fig. 4 Formulation activity in field-scale bioassays with $A$. indica cell culture formulations and commercial products. Formulation composition: $E$ base emulsion, $E X$ extract, $P$ photoprotector, $S$ stabilizers, Chem insect chemical insecticide (Ráfaga $\left.{ }^{\circledR}\right)$. Areas with the same letter do not exhibit significant differences according to the Fisher LSD test $(p<0.05)$
Affected leaf area in field-scale bioassays (\%)

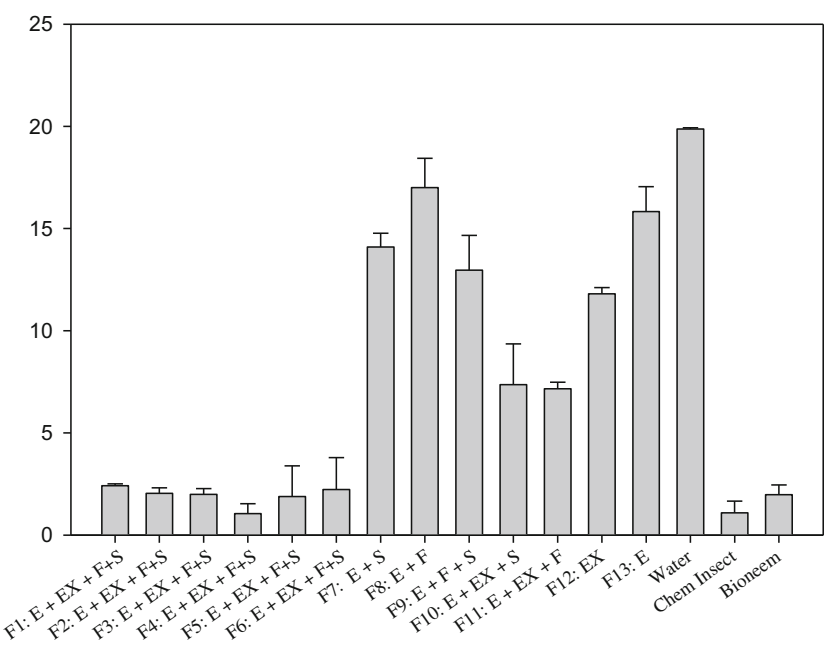

Treatments
Anthonomus eugenii. Azadirachtin applications of 104-208 mg/ L showed an intermediate effectiveness in the reduction of adults and damage to the fruit of the Habanero pepper. They, therefore, concluded that azadirachtin is a good alternative for controlling A. eugenii, and that it could replace the use of oxamyl and imidacloprid when infestation populations are not too large. The formulation designed in our investigation is the first one reported as a botanical active substance for controlling insects, whose active ingredient is obtained from neem cell culture. To make our formulation a completely environmentally friendly product, evaluation of other photoprotector compounds such as 4-aminobenzoic acid is recommended (Srivastava and Srivastava 2011; Sundaram and Curry 1996). Costa et al. (2017) reported the use of microcapsules of sugarcane bagasse lignin to improve the resistance of organic neem seeds extracts against abiotic factors, retaining its biological activity. Furthermore, malonic acid salts could be used as stabilizers of the extract. These products are toxic to neither humans nor the environment. Unlike the highly toxic chemical insecticides, the formulation presented in this paper and the new one that would contain other non-toxic compounds (photoprotector and stabilizers) could be used in organic agriculture. In this way, the presence of toxic agents in food would be reduced. This is the first time that a designed formulation for botanical active substance for controlling insects from $A$. indica cell culture extract is reported, and it is effective in controlling the armyworm. Additionally, biotechnological production would be independent of changes in the weather.

\section{Conclusions}

In this study, we investigated the photodegradation of limonoids from an $A$. indica cell culture extract under 368-nm UV light. The most stable emulsion contained water $(50.00 \% \mathrm{p} / \mathrm{p})$, castor oil $(49.80 \% p / p)$, and Tween $80(0.20 \% p / p)$. Relative phase separation occurred after $24 \mathrm{~h}$, and reversible separation was observed after 6 months. The formulation is slightly less stable than the base emulsion, although after 6 months, both were easily emulsified with light agitation. The formulation was composed of ethanolic extract $(0.76 \% \mathrm{p} / \mathrm{p}), 8$ hydroxinoline $(0.76 \% p / p)$, anthraquinone $(1.00 \% p / p)$, and epichlorohydrin $(1.00 \% \mathrm{p} / \mathrm{p})$. The formulation was applied in the field at $0.30 \%$, and its efficiency was comparable to that of the commercial product BioNeem $®$ and the chemical insecticide Ráfaga ${ }^{\circledR}$. The extract protector compounds helped to improve its antifeedant effect on $S$. frugiperda. In this investigation, we solved the problem of metabolite degradation in an ethanolic extract from $A$. indica cell culture applied in the field. Finally, this is the first time that a formulation for a botanical active substance for controlling insects is designed, using $A$. indica cell culture extract, and that it is efficient in controlling $S$. frugiperda in both the laboratory and field.

Acknowledgments This paper was supported by Colciencias (Departamento Administrativo de Ciencia, Tecnología e Innovación), Universidad Nacional de Colombia Sede Medellín, Biotecnología Vegetal and Biotecnología Industrial research groups. The authors also thank Clara Saldamando, Cesar Restrepo, and Guillermo Correa for their assistance. C. Zuleta-Castro thanks Paola Reyes and Aida Hurtado for their valuable help.

\section{References}

Adamson A, Gast A (1997) Physical chemistry of surfaces. California, Stanford

Ashley T, Mitchell E, Waddill V (1985) Control biológico del gusano cogollero en Florida. Ceiba 26:177-185

Avilés R, González N, Ramos N, Sotomayor E (2001) Efecto del NeemAzal en hojas de pimiento infestadas con huevos de Thryps 
palmi Karny (Thysanoptera: Thripidae). Boletín de Sanidad Vegetal. Plagas 27(2):193-197

Blaney W, Simmonds M, Ley S, Anderson J, Toogood P (1990) Antifeedant effects of azadirachtin and structurally related compounds on lepidopterous larvae. Entomologia Experimentalis et Applicata 55(2):149-160. doi:10.1111/j.1570-7458.1990.tb01358.x

Barrek S, Paisse O, Grenier-Loustalot M (2004) Analysis of neem oils by LC-MS and degradation kinetics of azadirachtin-A in a controlled environment. Characterization of degradation products by HPLCMS-MS. Anal Bioanal Chem 378(3):753-763. doi:10.1007/s00216003-2377-0

Capataz J (2005) Efecto de elicitores abióticos sobre la producción de metabolitos secundarios en suspensiones celulares de Azadirachta indica y su efecto sobre Spodoptera sp. Universidad Nacional de Colombia Sede Medellín, Dissertation

Capataz J, Orozco F, Vergara R, Hoyos R (2007) Efecto antialimentario de los extractos de suspensiones celulares de Azadirachta indica sobre Spodoptera frugiperda J.E.Smith en condiciones de laboratorio. Revista Facultad Nacional de Agronomía, Medellín 60(1):3703-3715

Costa E, Perlatti B, Da Silva E, Matos A, Da Silva M, Fernandes J, Zuin V, Da Silvad C, Forim M (2017) Use of Lignins from sugarcane bagasse for assembling microparticles loaded with Azadirachta indica extracts for use as neem-based organic insecticides. J Brazilian Chem Soc, São Paulo 28(1):126-135. doi:10.5935/01035053.20160155

Cruz M, Peral F, Troitiño M, Plaza M (2013) Evolucion historica de los principios de la quimica. Universidad Nacional de Educación a Distancia, Madrid

Dureja P, Johnson S (2000) Photodegradation of azadirachtin-a: a neembased pesticide. Curr Sci 79(12):1998-2001

García V, Carvajal E (2010) Eficiencia del control en campo de Spodoptera frugiperda J. Universidad Nacional de Colombia Sede Medellín, Dissertation

Giraldo F, Castaño C, Morales G, Lopez C, Galeano E (2002) Determinación de azadirachtina por cromatografía líquida de alta eficiencia. (HPLC) en semillas de árbol de neem ( $A$. indica) cultivadas en Colombia. Vitae 9(1):59-63

Griffin W (1949) Classification of surface-active agents by "HLB". Atlas Powder Company, Wilminston, Del

Johnson S, Dureja P (2002) Effect of surfactants on persistence of azadirachtin-a (neem based pesticide). J Environ Sci Health B Pestic Food Contam and Agric Wastes 37(1):75-80. doi:10.1081/ PFC-120002899

Johnson S, Dureja P, Dhingra S (2003) Photostabilizers for azadirachtinA (a neem-based pesticide). J Environ Sci Health B Pestic Food Contami Agric Wastes 38(4):451-462. doi:10.1081/PFC120021665

Kearney M, Allan E, Hooker J, Mordue J (1994) Anti-feedant effects of in vitro culture extracts of neem tree, Azadirachta indica against the desert locus (Schitocerca gregaria Fosskal). Plant Cell Tissue Org Cult 37:67-71. doi:10.1007/BF00048119

Kumar J, Parmar B (1999) Stabilization of azadirachtin A in neem formulations: effect of some solid carriers, neem oil, and stabilizers. J Agric Food Chem 47(4):1735-1739. doi:10.1021/jf980667t

López M, Hernández J, Pescador A, Molina J, Lezma R, Hamm J, Wiseman B (1999) Biological differences between five populations of fall armyworm (Lepidoptera: Noctuidae) collected from corn in Mexico. Fla Entomol 82(2):254-262

Martinelli S, Clark P, Zucchi I, Silvafilho M, Foster J, Omoto C (2007) Genetic structure and molecular variability of Spodoptera frugiperda (Lepidoptera: Noctuidae) collected in maize and cotton field in Brazil. Bull Entomol Res 97:225-231. doi:10.1017/ S0007485307004944

Morales, P, Noguera, Y. Escalona, E. Fonseca, O. Rosales, C. Salas, B. ... Sandoval, E. (2011). Sobrevivencia larval de Spodoptera frugiperda Smith con dietas artificiales bajo condiciones de laboratorio 1 larval survival of Spodoptera frugiperda Smith with artificial diet under laboratory conditions, 60(4), 375-380

Ospina I (2012) Actividad antifúngica del extracto crudo de Azadirachta indica A. Juss. de suspensión de células sobre hongos dermatofitos causantes de enfermedades patógenas al hombre. Dissertation, Universidad Nacional de Colombia Sede Medellín

Ostwald, W. (1888). Über die dissociations theorie der elektrolyte. Z Physik Chem pp 36-37 http://www.chemteam.info/Chem-History/ Ostwald-1888.html. Accessed 15 April 2016

Rajpal V (2005) Standardization of botanicals, testing and extraction methods of medical herbs. New Delhi, India

Ruiz E, Aguilar O, Cristóbal J, Tún J, Latournerie L, Pérez A (2009) Comparación de la efectividad de un insecticida botánico y dos químicos convencionales en el control del picudo (Anthonomus eugenii Cano) (Coleoptera: Curculionidae) en chile habanero (Capsicum chinense Jacq.) Fitosanidad 13(2):117-120

Santos Pinto E, Moreira E, Braz J, Dos Santos C (2013) The control and protection of cotton plants using natural insecticides against the colonization by Aphis gossypii Glover (Hemiptera: Aphididae). Acta Scientiarum Agronomy 35(2). doi:10.4025/actasciagron. v35i2.15764

Skoog D, West D, Holler J, Cruch S (2005) Fundamentos de química analítica, 8th edn. Thomson, Madrid, pp 910-912

Srivastava, S and Srivastava, A. (2011). Stability enhancement of Azadirachtin (a biopesticide) produced in vitro against atmospheric degradation. Annual Internatioanl Conference on Advances in Biotechnology, (Biotech), 978-981. doi:10.5176/978-981-088119-1

Sundaram K, Curry J (1996) Effect of some UV light absorbers on the photostabilization of azadirachtin, a neem based biopesticide. Chemosphere 32(4):649-659

Susaimanickam M, Veeramuthu A, Savrimuthu I, Subramanian E (2012) Formulation of a novel phytopesticide PONNEEM and its potentiality to control generalist herbivorous Lepidopteran insect pests, Spodoptera litura (Fabricius) and Helicoverpa armigera (Hübner) (Lepidoptera: Noctuidae). Asia Pac J Trop Dis:S720-S723. doi:10. 1016/S2222-1808(12)60251-5

Trujillo P, Zapata L, Hoyos R, Yepes F, Capataz J, Orozco F (2008) Determinación de la DL 50 y TL50 de extractos etanólicos de suspensiones celulares de Azadirachta indica sobre Spodoptera frugiperda. Revista Facultad Nacional de Agronomía 61(2):45644575

Villamil D, Naranjo N, Van Satrahlen M (2012) Efecto Insecticida del Extracto de Semillas de Neem (Azadirachta Indica). EntomoBrasilis $5(2): 125-129$ 